\title{
PENAMAAN PULAU-PULAU DI KABUPATEN LINGGA BERDASARKAN KAJIAN TOPONIMI DAN STUDI ETNOLINGUISTIK
}

\author{
Rahmat Muhidin, Lia Aprilina \\ Kantor Bahasa Kepulauan Bangka Belitung \\ Pos-el: rahmatmuhi@yahoo.com
}

\begin{abstract}
Abstrak
Penelitian ini membahas nama-nama pulau di Kabupaten Lingga yang berhubungan dengan sejarah penamaan pulau oleh warga sekitar pulau di Kabupaten Lingga. Penelitian bertujuan untuk mendeskripsikan nama-nama pulau di Kabupaten Lingga Provinsi Kepulauan Riau berdasarkan kajian toponimi dan etnolinguistik. Metode yang digunakan dalam penelitian ini adalah metode deskriptif dan studi literatur, data sekunder, data survei toponimi pulau, dan pengolahan data sebagai ancangan penelitian penamaan pulau-pulau di Kabupaten Lingga. Hasil penelitian menunjukkan bahwa penamaan pulau di Kabupaten Lingga mengacu pada beberapa indikator: (1) karakter dan potensi pulau; (2) dimensi pulau, bentuk pulau, dan posisi realif pulau; (3) jabatan dan nama orang yang bermukim di pulau tersebut; (4) legenda atas pulau yang bersangkutan; (5) penamaan pulau yang mempunyai maksud untuk memperingatkan, kehati-hatian terhadap sesuatu; (6) pulau pucong; (7) penamaan kumpulan atau jajaran pulau dalam satu nama atau pulau bersangkutan; dan (8) pulau serak artinya tersebar.
\end{abstract}

Kata kunci: penamaan, pulau, toponimi

\begin{abstract}
The research discusses names of islands in Lingga District relates to the history naming the island by people around the Lingga District. This research aims to describe names of the islands in Lingga District, Riau Island Province based on toponimy and ethnolinguistics study. The method used in this research was descriptive method and literature study. The data in this research was data secundery, islands toponimy survey data, and data processing as the research design. The result shows that the naming of islands at Lingga District refers to some indicators: (1) character and potention of the island, (2) dimension of the island, (3) title and name of people stay in the island, (4) legend of the island (5) naming of the island aims aim warning, awarness of something, (6) pucong island, (7) naming collection form of the islands into one name, and (8) serak islands or spread islands.
\end{abstract}

Key words: naming, island, toponimy

\section{PENDAHULUAN}

Kegiatan toponimi pulau mempunyai arti penting dan bernilai strategis secara nasional maupun internasional. Setiap negara anggota PBB harus melaporkan jumlah dan penamaan pulaunya kepada PBB setiap 5 tahun sekali (dalam bentuk National Report), secara nasional merupakan tanggung jawab bersama semua komponen bangsa (Rais, 2003).

Toponimi sering dikenal sebagai ilmu penamaan unsur geografis. Kajiannya menghasilkan daftar resmi nama geografis atau dikenal dengan gazeter. Setiap negara berhak menerbitkan dan melaporkan gazeter ini kepada 
dunia internasional; sebagai salah satu bukti inventarisasi kondisi geografis di wilayah kedaulatannya (Badan Riset Kelautan dan Perikanan, 2003).

Buku daftar pulau-pulau Indonesia (gazeter) masih dalam kondisi yang perlu disempurnakan. Dalam kaitannya untuk mengadministrasi wilayah Kedaulatan Negara Kesatuan Republik Indonesia (NKRI) Indonesia memiliki kepentingan untuk melaksanakan (1) pembakuan tulisan dan ejaan nama pulau, (2) menerbitkan daftar resmi nama-nama pulau di Indonesia, dan (3) menyusun prosedur pemberian, perubahan, dan penghapusan nama pulau (Badan Riset Kelautan dan Perikanan, 2003).

Seiring dengan berlakunya UU No.22 Tahun 1999 dan UU No. 32 Tahun 2004 tentang Pemerintahan Daerah, Pasal 21 dan Pasal 22 hak dan kewajiban daerah dalam pengelolaan sumberdaya wilayah menjadi sangat penting. Ketegasan batas wilayah pengelolaan dan inventarisasi sumberdaya yang terkandung di dalamnya merupakan salah satu langkah awal yang harus dilakukan oleh daerah sebagai masukan penting dalam perencanaan pengelolaan wilayah.

Pemanfaatan laut sebagai salah satu sumberdaya yang memiliki nilai strategis secara ekonomi., ekologi, dan budaya perlu mendapatkan perhatian yang merupakan tantangan tersendiri bagi daerah yang memiliki batas laut. (Dahuri, 2004). Nilai strategis yang mengacu pada aspek ekonomi adalah pembudidayaan ikan pada jaring apung di sekitar pulau untuk budi daya ikan kerapu, ikan kakap, jenis ikan karang, ikan pelagis, dan lainnya yang memiliki nilai ekonomis yang tinggi di pasar domestik atau manca negara. Nilai strategis secara ekologis adalah sebaran terumbu karang di sekitar pulau-pulau di Kabupaten Lingga yang berlimpah memungkinkan tersedianya makanan organik yang berlimpah untuk ikan-ikan yang hidup di sekitar terumbu karang. Selain itu, juga dapat menjadi penyeimbang habibat ikan berkembang biak secara alamiah. Nilai budaya dengan pemanfaatan laut secara strategis adalah terjaganya budaya maritim di daerah kepulauan seperti Kepulauan Lingga. Masyarakat maritim seperti di Kepulauan Lingga ini tentu memperkaya khasanah kebudayaan Indonesia yang heterogen.

Pulau-pulau yang tersebar di perairan laut merupakan salah satu sumberdaya yang sangat potensial sebagai lokasi pengembangan industri wisata, perikanan baik laut maupun budidaya, pemukiman, lokasi penelitian konservasi alam, budaya dan lain sebagainya. Pengelolaan data yang baik dengan dukungan data yang lengkap diharapkan akan menghasilkan ketahanan ekonomi daerah yang mantap dalam menghadapi persaingan regional maupun global (Dahuri,2000).

Dalam kaitannya pengelolaan pulau sebagai sumberdaya wilayah,maka identfikasi dan inverntarisasi pulau-pulau dilakukan secara sistematik. Titik berat kegiatan yang dilakukan adalah mengidentifikasi dan menginventarisasi pulau-pulau di perairan Indonesia melalui pendekatan metode pemetaan yang diintegrasikan dengan metode toponimi (survei penamaan geografis).

Badan Riset Kelautan dan Perikanan (2003) menyatakan bahwa data dasar penting tentang Indonesia sebagai suatu wilayah negara kepulauan yang belum didukung oleh dokumen resmi adalah jumlah pulau. Jumlah pulau Indonesia yang dinyatakan dalam angka-angka yang berbeda dari sumber yang berbeda pula. Data jumlah pulau di Indonesia yang berjumlah 17.504 pulau (Depdagri, 2004) sebagian besar masih belum bernama seperti terlihat pada Tabel 1.

Memperhatikan perbedaan data pulau di Indonesia di atas dapat mengarah pada suatu kemungkinan bahwa permasalahan pendataan pulau di Indonesia (1) belum dilaksanakan sesuai prosedur baku pendataan pulau secara efektif, (2) belum dilaksanakan secara sistematis, (3) belum berjalan secara optimal secara 
kelembagaan, (4) belum berjalan dengan baik dalam penerapan standar basis data pulau, atau (5) belum membekali sumber daya manusia yang dilibarkan dalam pendataan pulau dengan kemampuan yang memadai.

Sejak Perang Dunia II usai, dan PBB dibentuk, badan ini menaruh perhatian besar tentang usaha standardisasi nama-nama geografis, karena sebenarnya banyak faktor yang ikut campur dalam komunikasi yang efektif dari nama-nama geografis antara lain: banyak tempat yang mempunyai lebih dari satu nama dalam satu negara yang sama atau di negara lain, banyak nama diaplikasikan pada lebih satu unsur, nama yang dieja dalam berbagai cara, orang-orang dalam satu negara atau satu bahasa memberi nama dari tempat atau negara lain yang berbeda dengan nama lokalnya, perlu percepatan usaha romanisasi nama-nama geografis dari sistem tulisan non-Romawi (Rais, 1992).

Indonesia sebagai negara maritim harus mengetahui secara pasti jumlah pulau yang dimiliki dengan informasi nama dan posisi. Informasi ini sangat diperlukan dalam pengelolaan pulau sebagai sebagai salah satu sumber daya wilayah. Pendataan pulau dilakukan dengan mengkaji secarakomprehensif data pulau-pulau berdasarkan data dari berbagai pihak yang telah melakukan pendataan pulau selama ini (Badan Riset Kelautan dan Perikanan, 2003).

Provinsi Kepulauan Riau ditetapkan sebagai lokasi survei toponimi pulau karena memiliki kuantitas yang besar dengan karakteristik yang khas; penamaan pulau-pulau di daerah ini dilakukan dalam berbagai bahasa lokal dan latar belakang. Beberapa catatan sejarah juga telah melatarbelakangi keragaman toponimi pulau di daerah ini.

Permasalahan dalam penelitian ini adalah (1) apakah nama-nama pulau di Kabupaten Lingga memiliki karakteristik yang khas, dan (2) apakah yang melatarbelakangi penamaan nama pulau-pulau di Kabupaten Lingga dengan menggunakan bahasa lokal?
Tujuan dilaksanakan penelitian ini di Kabupaten Lingga adalah sebagai berikut.

(1) Mendeskripsikan nama-nama pulau yang terdapat di Kabupaten Lingga dengan tetap memperhatikan nama yang memiliki karakteristik yang khas di wilayah ini.

(2) Mendeskripsikan nama-nama pulau itu dengan mengaitkannya dengan sejarah lokal dan menjelaskannya pemakaian nama pulau yang bersangkutan mengapa menggunakan bahasa lokal yang dimaksudkan.

\section{TEORI DAN METODE}

Dalam melaksanakan penelitian ini, peneliti mengacu pada pendapat pakar toponimi dan pakar etnolinguistik. Berkaitan dengan hal tersebut, kajian para pakar toponimi dan etnolinguistik disampaikan di bawah ini.

Toponimi merupakan salah satu cabang ilmu kebumian yang mengkaji dan mempelajari permasalahan penamaan unsur geografi baik buatan alam (pulau, tanjung, selat, gunung, bukit, lembah, danau, sungai, dan sebagainya), maupun buatan manusia (bandara, bendungan, waduk, jembatan, terowongan, mercusuar, candi, dan sebagainya). Ilmu ini menjadi penting sejak peta bertindak sebagai media komunikasi antarbangsa.

Selain mempelajari masalah utama, ilmu ini juga mengkaji pembakuan penulisan, ejaan pengucapaan (fonetik). Sejarah penamaan serta korelasi nama dengan kondisi alam atau sumber daya dimiliki sebuah unsur geografi (BRKP, 2003). Penamaan dan pembakuan namanama unsur geografi telah menjadi perhatian masyarakat internasional sejak lama. Hal tersebut ditunjukkan dengan dibentuknya UNGEGN (United Nation Groups of Experts on Gographical Name), untuk mendukung usaha standarisasi nama geografi pada tingkat nasional ataupun internasional (Kusumah, 2007).

Dalam kajian toponimi pulau,hal-hal yang mendasar yang harus dipahami oleh seorang 
peneliti adalah definisi pulau. Pulau yang dimaksud mengacu pada definisi United Nations Convention on the Law of the Sea (UNCLOS) 1982 Bab VIII Pasal 121 (United Nation, 1983) yang menyebutkan bahwa "pulau adalah daerah daratan yang terbentuk secara alami yang dikelilingi oleh air dan ada di permukaan air pada saat air pasang. Jika suatu daratan ditumbuhi berbagai vegetasi yang pada pasang tinggi tidak tenggelam, ia tetap tidak bisa disebut pulau jika daratan yang menjadi platformnya terendam air dan tidak muncul di permukaan.

Dalam pandangan etnolinguistik, terdapat keterkaitan antara bahasa dengan pandangan dunia penuturnya. Boas menyebutkan bahwa pendeskripsian terhadap suatu bahasa hendaknya didasarkan pada apa yang ada di dalam bahasa itu sendiri (di dalamnya berdasarkan budaya dan pandangan hidup), bukan berdasarkan pada tata bahasa lain. Pengertian tersebut juga didukung oleh pendapat Troike (2003:1) mengenai etnografi bahwa ethnography is a field of study which concerned primarily with the description and analysis of culture, and linguistics is a field concerned, among other things, with the description and analysis of language code 'etnografi merupakan studi lapangan yang membahas deskripsi dan analisis budaya pada pokok konsentasinya, dan menghubungkannya dengan linguistik sebagai studi lapangan. Di sisi lain, penjelasannya disertai deskripsi dan analisis kode bahasa'.

Pendapat lain mengenai etnolinguistik juga dikemukakan oleh Duranti (1997:2) yang menyatakan bahwa etnolinguistik adalah kajian bahasa dan budaya yang merupakan subbidang utama dari antropologi (ethnolinguistics is part of a conscious attempt at consolidating and redefining the study of language and culture as one of the major subfield of anthropology 'etnolinguistik adalah bagian dari upaya sadar yang mengkonsolidasikan dan mendefinisikan kembali studi bahasa dan budaya sebagai salah satu subbidang kajian dalam antropologi').
Lebih lanjut dijelaskan bahwa etnolinguistics is the study of speech and language within the context of anthropology 'etnolinguistik merupakan studi ujaran dan bahasa yang berada dalam konteks antropologi'.

Berdasarkan pengertian di atas dapat disimpulkan bahwa etnolinguistik merupakan studi linguistik yang menyelidiki bahasa terkait dengan budaya suku bangsa di manapun berada. Kajian etnolinguistik tidak terbatas pada suku bangsa yang tidak mempunyai tulisan saja, namun yang sudah mempunyai tulisan pun dapat dikaji.

Sedangkan macam atau sifat penelitian ini adalah penelitian lapangan yang digabungkan dengan studi pustaka yang relevan dengan kajian ini. Adapun yang menjadi sumber data penelitian ini adalah penduduk yang merupakan (1) etnik Melayu Linggayang berdomisili di seluruh Kabupaten Lingga Provinsi Kepulauan Riau (2) memahami budaya dan tata cara adat budaya Lingga dan sekitarnya (3) berusia antara 20-65 tahun, (4) alat wicara lengkap dan tidak cacat pendengaran, (5) dan pendidikan maksimal SMA sederajat.

\section{Instrumen Pengumpulan Data}

Penelitian ini menggunakan instrumen pengumpul data sebagai penjaring data dengan menyebar daftar tanyaan terkait toponimi dan etnolinguistik. Daftar tanyaan ini diiringi dengan pertanyaan lepas yang berhubungan dengan toponimi dan etnolinguistik terutama berkaitan dengan penamaan pulau dan sejarahnya. Penjaringan data tersebut disertai perekaman jika diperlukan.

\section{Objek Kajian}

Kajian penelitian ini dalam pelaksanaannya menggunakan metode deskriptif-kualitatif. Penggunaan metode deskriptif-kualitatif bertujuan untuk dapat mendapatkan toponimi dan etnolinguistik secara proporsional. Sudaryanto (1993:62) mengungkapkan bahwa penelitian deskriptif dilaksanakan hanya berdasarkan fakta yang ada atau fenomena yang 
secara empiris hidup di antara para penuturnya yang dihasilkan atau dicatat berupa perian bahasa yang biasa disebut potret. Perian ini tidak menyebutkan benar salahnya penggunaan bahasa oleh para penuturnya.

\section{Metode dan Teknik Pengumpulan Data}

Penelitian lapangan dan studi kepustakaan ini dilakukan pada bulan Agustus-Oktober 2015 di Kecamatan Lingga. Peneliti mengumpulkan data di lapangan dengan cara wawancara, pengamatan, perekaman, dan dokumentasi. Prosedur pengumpulan data mengacu pada pendapat Moleong (2001) berupa observasi lapangan, wawancara, perekaman, dokumentasi dan studi pustaka. Dalam hal ini, peneliti harus mempersiapkan buku catatan, dan tape recorder, untuk merekam informasi lisan dari penutur bahasa Melayu Kepulauan Lingga. Samarin (1988:168) mengisyaratkan teknik pemancingan untuk mendapatkan data yang baik dengan dua cara yaitu: (1) pemancingan terjadwal, (2) pemancingan analitis. Pemancingan terjadwal dilakukan karena kekurangtahuan atau ketidaktahuan terhadap data yang ada atau data baru. Pemancingan analitis dilaksanakan karena data yang diambil mengacu pada bidang tertentu dan membutuhkan informasi yang tidak sedikit.

Metode dan teknik analisis data dalam menganalisis penggunaan dan penamaan nama pulau di Kabupaten Lingga dengan menggunakan metode deskriptif yang disertai pemilahan data dengan menjabarkan pemakaian penamaan pulau-pulau di Kabupaten Lingga seperti apa adanya. Hasil temuan yang diperoleh di lapangan dikelompokkan berdasarkan kategori masing-masing. Dengan kata lain, tiap penamaan pulau tersebut dideskripsikan sesuai ranahnya masing-masing.

Selain itu, analisis pulau ini dilakukan dengan menggunakan metode deskriptif dan studi literatur seperti yang pernah dilakukan penelitian sebelumnya. Dalam mengkaji namanama pulau di Kabupaten Lingga dengan tetap memperhatikan hal-hal berupa penggunaan data sekunder. Penggunaan data sekunder merupakan data pelengkap yang digunakan sebagai bahan acuan dalam melaksanakan identifikasi. Selain itu juga untuk memudahkan proses identifikasi sampai didapat data yang cukup akurat (seperti halnya peta referensi, citra satelit, foto udara serta data pasang surut).

Lebih lanjut, dalam pelaksanaannya, kegiatan ini didahului dengan desain survei, pelaksanaan survei, dan pengolahan data hasil survei. Kegiatan yang disurvei antara lain dengan wawancara dengan masyarakat tentang sejarah nama dan posisi relatif pulau, konsultasi dengan pejabat setempat, dan pengamatan genesa pulau serta pengambilan posisi pulau sebagai data referensi. Bila memungkinkan koordinat titik tengah atau centroid dari pulau, bila pulau cukup besar, posisinya diukur dengan titik yang merupakan ujung-ujung pulau tersebut. Selanjutnya dilakukan pengolahan data yang diperoleh dan dikumpulkan kemudian diolah lagi berdasarkan kategori yang diharapkan. Jenis data titik koordinat diolah dengan peta referensi secara spasial untuk menganalisa pulau dan hasilnya digabungkan dengan hasil wawancara.

Berdasarkan kajian studi pustaka, dapat diperoleh data bahwa pembakuan istilah dan nama pulau mengacu pada nama generik. Tiaptiap unsur geografi di Indonesia terdiri dari dua bagian yakni: nama generik yaitu sebutan untuk unsur tersebut dalam bahasa Indonesia atau bahasa lokal/etnis serta nama-nama spesifik atau nama diri dari unsur tersebut.

\section{HASIL DAN PEMBAHASAN}

\section{Pembakuan Nama Unsur Geografis Pulau}

Dalam pembakuan nama-nama pulau di Kabupaten Lingga, beberapa hal yang dapat diperhatikan adalah sebagai berikut:

1. Dalam penulisan nama unsur geografi ditulis terpisah antara nama generik dan nama spesifik; 
2. Sebagian nama spesifik di Indonesia, khususnya nama kota, pemukiman, dan sebagainya, memuat juga nama generik dalam nama spesifiknya, seperti nama-nama kota memakai gunung, bukit, tanjung, teluk, pulau, dan seterusnya dalam nama spesifiknya. Dalam kasus ini nama spesifik tersebut ditulis dalam satu kata, contohnya: Kota Gunungsitoli, Kota Bukittinggi, Kota Tanjungpinang, Kota Tanjungpandan, dan sebagainya;

3. Bila suatu nama spesifik ditambah dengan sifat di belakangnya atau penunjuk arah maka ditulis terpisah;

4. Jika nama spesifik yang terdiri dari kata berulang, ditulis sebagai satu kata;

5. Nama spesifik terdiri dari kata benda diikuti dengan nama generik,maka ditulis sebagai satu kata;

6. Jika nama spesifik terdiri dari empat kata atau lebih, disarankan tidak memakai nama yang panjang.

Berdasarkan data yang dikumpulkan terkait cerita asal-usul penamaan pulau, pada umumnya, penamaan pulau-pulau itu didasarkan pada faktor geografis, yaitu berupa penamaan yang berkenaan dengan bentuk permukaan bumi, tumbuh-tumbuhan, dan penduduk. Untuk lebih konkretnya penamaan pulau di Kabupaten Lingga dapat dikelompokkan pada tujuh kategorial yaitu:

1. Sejarah

2. Nama tumbuh-tumbuhan

3. Bentuk atau posisi pulau

4. Penamaan berdasarkan topografis atau keadaan permukaan bumi

5. Gabungan topografis dan sifat manusia

6. Suku penduduk, dan

7. Fungsi pulau atau profesi penduduknya

Berdasarkan hasil pengamatan dan kajian pustaka, penamaan pulau-pulau di Kabupaten Lingga sebagian besar dapat dikelompokkan berdasarkan pada kategori sebagai berikut.

\section{Karakter dan Potensi Pulau}

Pulau-pulau diberi nama oleh masyarakat berdasarkan sesuatu yang dapat ditemukan dan menjadi ciri khas pulau bersangkutan. Nama-nama pulau yang mengacu pada karakter dan potensi pulau antara lain sebagai berikut.

1. Pulau Airresi: arti Pulau Airresi adalah pulau yang airnya berasa payau (resi)

2. Pulau Bakung Besar dan Pulau Bakung Kecil: arti Pulau Bakung Besar dan pulau Bakung Kecil adalah mengacu pada hal/ sesuatu bahwa di pulau ini banyak dijumpai tumbuhan bakung yang secara liar tumbuh hingga saat ini. Tumbuhan ini tumbuh subur di kedua pulau ini.

3. Pulau Air: penamaan Pulau Air dikarenakan di pulau ini banyak terdapat air tawar, karenanya pulau tersebut banyak air tawar yang melimpah, sehingga dinamai Pulau Air. Pulau Lipan: penamaan pulau ini dengan Pulau Lipan dikarenakan di pulau ini banyak terdapat binatang lipan.

4. Pulau Batu Buntal: Penamaan Pulau Batu Buntal ini dikarenakan di sekitar perairan pulau ini banyak terdapat ikan buntal; tapi di pulau ini ikan buntal sekarang ini mulai berkurang karena alasan morfologis pulau dan topografi kelautan.

5. Pulau Burung: Penamaan pulau ini dengan sebutan Pulau Burung karena di pulau ini banyak dijumpai burung secara liar yang hinggap di atas pohon sebagai tempat hinggapannya

6. Pulau Mutus: Penamaan pulau ini dengan nama Pulau Mutus karena pulau ini putus. Mutus artinya putus. Pulau yang putus atau terpisah dari pulau induknya.

7. Pulau Punai: Penamaan pulau ini dengan Pulau Punai karena di pulau ini banyak dijumpai burung punai liar yang hinggap di atas pohon.

8. Pulau Rusukbuaya: Penamaan pulau ini dengan nama Pulau Rusukbuaya karena 
di pulau ini banyak dijumpai rusuk-rusuk buaya.

9. Pulau Besi: Penamaan pulau ini dengan nama Pulau Besi karena di pulau ini banyak dijumpai biji besi. Karena pulau tersebut kaya akan biji besi yang melimpah, sehingga pulau ini dinamai pulau besi.

10. Pulau Gelombang: Penamaan pulau ini dengan sebutan Pulau Gelombang karena di sekitar pulau ini banyak dijumpai gelombang besar.

11. Pulau Kalan Besar dan Pulau Kalan Kecil: Penamaan pulau ini dengan sebutan Pulau Kalan Besar dan Pulau Kalan Kecil karena di pulau ini banyak dijumpai tempat kalan atau pangkalan kapal hingga saat ini.

12. Pulau Kekek: Penamaan pulau ini dengan sebutan pulau Kekek karena di pulau ini banyak ditemukan ikan kekek yang berlimpah hingga saat ini.

13. Pulau Kelubi: Penamaan pulau ini dengan sebutan Pulau Kelubi karena di pulau ini banyak ditemukan tumbuhan kelubi yang secara liar tumbuh subur.

14. Pulau Kukur: Penamaan pulau ini dengan sebutan Pulau Kukur karena di pulau ini banyak kayu yang dipergunakan untuk alat kukur kelapa.

15. Pulau Limau: Penamaan pulau ini dengan sebutan Pulau Limau karena di pulau ini banyak ditemukan pohon limau yang tumbuh secara liar dan berjumlah cukup banyak.

16. Pulau Mentigi: Penamaan pulau ini dengan sebutan Pulau Mentigi karena di pulau ini banyak ditemukan pohon mentigi yang tumbuh secara liar. Pohon mentigi mempunyai kayu yang sangat keras.

17. Pulau Nyamuk: Penamaan pulau ini dengan sebutan Pulau Nyamuk karena di pulau ini banyak terdapat nyamuk yang sering mengganggu para nelayan yang singgah di daerah ini.
18. Pulau Nyeri: Penamaan pulau ini dengan sebutan Pulau Nyeri karena di pulau ini banyak batu-batu yang membuat kaki nyeri bila orang menginjaknya.

19. Pulau Pandan: Penamaan pulau ini dengan sebutan Pulau Pandan karena di pulau ini banyak dijumpai tanaman pandan.

20. Pulau Petai: Penamaan pulau ini dengan sebutan Pulau Petai karena di pulau ini banyak dijumpai tanaman petai yang hidup subur dan berbuah lebat.

21. Pulau Planduk Besar dan Kecil: Penamaan pulau ini dengan sebutan Pulau Planduk Besar dan Pulau Planduk Kecil karena di pulau ini banyak dijumpai binatang pelanduk atau kancil.

22. Pulau Kapas Besar dan Pulau Kapas Kecil: Penamaan pulau ini dengan sebutan Pulau Kapas Besar dan Pulau Kapas Kecil karena pada kedua pulau ini banyak dijumpai tanaman kapas yang tumbuh dengan sangat lebat.

23. Pulau Selada: Penamaan pulau ini dengan sebutan Pulau Selada karena di pulau ini banyak dijumpai tanaman selada.

24. Pulau Siput Besar dan Pulau Siput Kecil: Penamaan pulau ini dengan sebutan Pulau Siput Besar dan Pulau Siput Kecil karena pada kedua pulau ini banyak ditemukan siput-siput batu.

25. Pulau Talas: Penamaan pulau ini dengan sebutan Pulau Talas karena di pulau ini banyak dijumpai tanaman talas yang cukup banyak.

26. Pulau Telur: Penamaan pulau ini dengan sebutan pulau telur karena di pulau ini merupakan tempat bertelur penyu sehingga dinamakan pulau telur.

27. Pulau Tikus: Penamaan pulau ini dengan sebutan Pulau Tikus karena di pulau ini banyak dijumpai tikus yang hidup bergerombol/berkelompok. 
Dimensi Pulau, Bentuk Pulau, dan Posisi Realif Pulau

Ukuran pulau menjadi pedoman bagi masyarakat dalam memberikan nama pulau di sekitar tempat bermukim dan mencari nafkah. Beberapa pulau dengan penamaan mengacu pada dimensi dan bentuk pulau, antara lain.

1. Pulau Lalang: Pemberian nama pulau ini dengan sebutan Pulau Lalang karena letaknya menghalangi jalan air.

2. Pulau Batu Belobang: Penamaan pulau ini dengan sebutan Pulau Batu Belobang karena pulau batu di tengahnya ada lubang yang bisa dilewati sehingga pulau ini disebut Pulau Batu Belobang.

3. Pulau Benaung: Benaung artinya tempat berteduh. Penamaan pulau ini dengan sebutan Pulau Benaung karena seringkali orang/nelayan yang datang ke pulau ini berteduh/bersembunyi dari angin puyuh/ badai yang datang sewaktu-waktu. karenanya merupakan tempat bernaung atau berteduh kapal jika datang badai.

4. Pulau Barat: Penamaan pulau ini dengan sebutan Pulau Barat karena pulau ini letaknya di bagian barat dari Kecamatan Senayang.

5. Pulau Cening: Penamaan pulau ini dengan sebutan Pulau Ceneng karena pulau ini terletak di muka Sungai Cening.

6. Pulau Batugajah: Penamaan Pulau Batu Gajah karena batu ini bentuknya sebesar gajah yang terletak di ujung pulau ini.

7. Pulau Anakpulau: Penamaan pulau ini dengan sebutan Pulau Anakpulau karena pulau ini bentuknya kecil. Anak artinya kecil. Karena bentuknya kecil sehingga pulau ini dinamakan anak pulau.

8. Pulau Buaya: Penamaan pulau ini dengan sebutan Pulau Buaya karena pulau ini bentuknya seperti buaya terletak tergeletak sehingga pulau ini dinamakan Pulau Buaya.
9. Pulau Bulat: Penamaan Pulau Bulat dikarenakan pulau ini mempunyai bentuk yang bulat. Pulau ini terletak di Kecamatan Senayang.

10. Pulau Malang Merah: Penamaan pulau ini dengan sebutan Pulau Malang Merah karena pulau ini berwarna merah bila dilihat dari kejauhan. Malang dalam bahasa lokal artinya batu. Pulau Malang Merah bila dilihat dari jauh tampak berwarna merah.

11. Pulau Malang Tai Koyo: Penamaan pulau ini dengan sebutan Pulau Malang Tai Koyo karena pulau ini bentuknya seperti kotoran (tahi) anjing. Koyo artinya anjing.

12. Pulau Malang Berhias: Penamaan pulau ini dengan sebutan Pulau Batu berhias karena karena batu itu tampak indah. Maksudnya adalah batu ini bila dilihat dari kejauhan batu ini terlihat seperti gadis yang sedang berhias diri atau bersolek.

13. Pulau Malang Cahaya: Penamaan pulau ini dengan sebutan Pulau Malang Cahaya karena pulau batu ini bercahaya pada malam hari bila terkena sinar bulan.

14. Pulau Malang Hitam: penamaan pulau ini dengan sebutan Pulau Malang Hitam karena pulau batu ini berwarna kehitaman bila terkena sinar bulan.

15. Pulau Malang Tikus: Penamaan pulau ini dengan nama Pulau Malang Tikus karena bentuk pulau batu ini yang berwujud seperti tikus.

16. Pulau Panjang: Penamaan pulau ini dengan sebutan Pulau Panjang karena pulau ini bentuknya pulau yang panjang dan berwujud pulau pulau panjang besar dan pulau panjang kecil.

17. Pulau Payung: Penamaan Pulau Payung karena pulau ini berwujud seperti payung.

18. Pulau Lampu: Penamaan pulau ini karena pulau ini yang terletak di gugusan pulau berhala ini terdapat mercusuar sehingga masyarakat setempat menamakannya pulau lampu. 
19. Pulau Tengah: Penamaan ini dengan sebutan Pulau Tengah karena pulau ini terletak di tengah-tengah di antara Pulau Lalang dan Pulau Keling.

20. Pulau Terlipat: Penamaan pulau ini dengan nama Pulau Terlipat karena pulau ini terletak terlipat di antara pulau.

21. Pulau Tenang Besar, Pulau Tenang Tengah, dan Pulau Tenang Kecil: Penamaan pulau ini dengan nama Pulau Tenang Besar, Pulau Tenang Tengah, dan Pulau Tenang Kecil dikarenakan di perairan di sekitar pulau ini berarus tenang.

Jabatan dan Nama Orang yang Bermukim di Pulau Tersebut:

22. Pulau Mentulat: Mentulat adalah nama orang yang tinggal di pulau ini.

Legenda atas Pulau yang Bersangkutan

23. Pulau Lingga: Penamaan pulau ini dengan sebutan Pulau Lingga ini berasal dari kata lingga yang artinya gigi naga. Menurut cerita rakyat, dahulu ada pelaut dari negeri Tiongkok berlayar melewati Pulau Lingga kemudian mereka berteriak ling-ga yang berarti gigi naga. Pulau ini bila dilihat dari bagian barat gunungnya menyerupai 2 gigi taring.

24. Pulau Monyet Besar: Penamaan pulau ini dengan nama Pulau Monyet Besar ini dihubungkan dengan cerita yang berkembang di masyarakat, konon kabarnya dahulu kala di pulau ini dijumpai monyet yang besar.

25. Pulau Matianak: Penamaan pulau ini dengan nama Pulau Matianak karena dahulu kala pernah ada anak kecil di pulau ini sehingga pulau ini dinamakan Pulau Matianak.

26. Pulau Pahat: Penamaan Pulau Pahat pada pulau ini karena di pulau ini terdapat batu bekas pahatan Jepang.

27. Pulau Selamat: Penamaan pulau ini dengan Pulau Selamat karena dihubung- kan dengan cerita dahulu kala di pulau ini terdapat orang selamat dari petaka.

28. Pulau Tapa: Penamaan pulau ini dengan sebutan Pulau Tapa karena di pulau ini dahulu kala dijadikan tempat bertapa seseorang untuk mendapatkan kesaktian.

Penamaan kumpulan atau jajaran pulau dalam satu nama atau pulau bersangkutan.

29. Pulau Serak berarti tersebar. Pulau yang terdapat beberapa buah pulau yang letaknya berserakan.

Penamaan pulau yang mempunyai maksud untuk memperingatkan, kehati-hatian terhadap sesuatu.

30. Pulau Pucong: Penduduk harus hati-hati karena pulau ini tersebut angker, Pucong artinya pocong atau kain kafan mayat.

Secara keseluruhan pulau-pulau kecil tersebar dari utara ke selatan, meskipun demikian sebagian besar terkonsentrasi di bagian utara lokasi survei. Di bagian selatan wilayah penelitian, pulau-pulau kecil tersebar di sebelah barat dan selatan Pulau Singkep, kecuali ada sebagian kecil jauh di sebelah tenggara. Di bagian tengah atau di sekitar Pulau Lingga, pula-pulau kecil tersebar sebagian besar di sebelah timur Pulau Lingga, dan beberapa di sebelah selatannya. Di bagian utara wilayah survei, pulau-pulau kecil tersebar di bagian tengah, barat hingga utara dengan jumlah relatif banyak.

Pulau-pulau yang belum teregistrasi tersebar juga dari utara hingga selatan wilayah penelitian. Di sebelah selatan tersebar relatif berjauhan dengan jumlah yang relatif sedikit, sedangkan di utara tersebar relatif berdekatan dengan jumlah yang relatif banyak.

\section{Pulau-pulau di Kecamatan Senayang}

Survei yang dilakukan di Kecamatan Senayang mengambil lokasi dari pulau Katanglingga (0 derajat 30 derajat 18.36 derajat LU; 104 derajat 24.41 derajat, 76 BT di utara hingga 
Pulau Anakpulau (0 derajat 7.34.72LU, 104 derajat 29 drajat 7.26 BT) di selatan. Peta persebaran pulau kecil di Kecamatan Senayang memperlihatkan bahwa pulau kecil tersebar hampir semua di sebelah utara Pulau Lingga. Kecamatan Senayang jumlah total adalah sebanyak 315 buah pulau, dengan jumlah pulau yang teregistrasi sebanyak 149 buah pulau, dan belum teregistrasi sebanyak 166 buah pulau.

Persamaan terjadi antara penemuan lapangan dengan penamaan Dishidros sebanyak 55 buah, penemuan lapangan dengan penamaan gazeter sebanyak 38 buah. Penamaan Dishidros dengan penamaan gazeter sebanyak 116 buah dan persamaan ketiganya 37 buah pulau.

Perbedaan yang terjadi adalah antara penemuan lapangan dengan penamaan Dishidros sebanyak 260 buah, antara penemuan lapangan dengan penemuan gazeter sebanyak 277 buah. Antara penamaan Dishidros dengan penamaan gazeter sebanyak 199 buah dan tidak terdapatnya persamaan penamaan suatu pulau dari ketiganya sebanyak 180 buah pulau. Perbedaan itu berupa penamaan pulau yang belum teregistrasi, perbedaan pengucapan yang masih terlihat adanya hubungan, dan perbedaan pengucapan tidak terlihat hubungan sama sekali.

Perbedaan penamaan yang masih terlihat adanya hubungan dapat dilihat pada penamaan contohnya pada Pulau Air (0 derajat 8.32, 03 LU 104 derajat 26 derajat 36 derajat 06 BT), misalnya, penemuan lapangan masyarakat setempat menyebutnya Pulau Air, sedangkan penamaan Dishidros adalah Pulau Ayer, dan belum ada data menurut gazeter. Contoh lain adalah Pulau Anakileh (0 derajat $\mathrm{O}$ derajat 49.57 derajat LS 104 derajat 41 .0.64 BT. Penemuan di lapangan adalah Pulau Anakileh, sedangkan penamaan Dishidros adalah Pulau Anakileuh, dan menurut gazeter adalah Pulau Anakkileuh.
Perbedaan penamaan yang tidak terlihat adanya hubungan dapat dilihat pada penamaan Pulau Tapa. Menurut penemuan lapangan Pulau Tapa, sedangkan menurut penamaan Dishidros adalah Pulau Briehdarat, dan Pulau Brieh Darat menurut gazeter. Contoh lain adalah penyebutan Pulau Punut. Adapun penyebutan masyarakat dengan Pulau Punut, sedangkan menurut penyebutan Dishidros dan gazeter adalah Pulau Botot.

Persamaan dan perbedaan penamaan pulau berdasarkan survei lapangan bila disandingkan dengan data Dishidros dan gazeter di Kabupaten Lingga menunjukkan bahwa di Kecamatan Lingga Utara jumlah pulau total adalah 12 buah pulau, dengan jumlah pulau yang teregistrasi sebanyak 8 buah, dan belum teregistrasi sebanyak 4 buah. Persamaan hasil pengamatan yang dilakukan peneliti dengan Dishidros di Kecamatan Lingga Utara adalah berjumlah 12 pulau. Namun, Dishidros belum menunjukkan 12 pulau tersebut belum teregistrasi. Sedangkan peneliti menemukan bahwa kedua belas pulau tersebut ditemukan 8 pulau sudah teregistrasi dan 4 pulau belum teregistrasi dalam gazeter. Dengan demikian, penamaan pulau sebanyak 4 buah yang sudah ditemukan di lapangan, sesegera mungkin dimasukkan ke dalam gazeter nasional. Sedangkan perbedaan antara temuan peneliti dengan Dishidros yaitu belum semua pulau yang sudah dinamai masuk ke dalam gazeter nasional. Penamaan pulau tersebut pun harus mengacu pada kaidah pembuatan toponimi wilayah secara nasional.

Persamaan terjadi karena antara penemuan lapangan dengan penamaan Dishidros sebanyak 5 buah, penemuan lapangan dengan penamaan gazeter 2 buah, penamaan Dishidros dengan penamaan gazeter sebanyak 5 buah dan persamaan ketiganya sebanyak dua buah. Temuan ini berada di Kabupaten Lingga. Hal ini menunjukkan bahwa antara temuan peneliti di lapangan dengan penamaan gazeter serta temuan yang dilakukan Dishidros belum 
seragam. Penamaan pulau yang terdapat di Kecamatan Lingga Utara sampai Kecamatan Lingga diperlukan pemilahan dan pencatatan oleh lembaga atau instansi terkait secara berkesinambungan.

Perbedaan terjadi adalah penemuan lapangan dengan penamaan Dishidros sebanyak 7 buah. Antara penemuan lapangan dengan penamaan gazeter sebanyak 10 buah, antara penamaan Dishidros dengan gazetir sebanyak 7 buah dan tidak terdapatnya persamaan penamaan suatu pulau dari ketiganya sebanyak 4 buah pulau. Survei ini dilaksanakan di Kecamatan Lingga Utara dengan mengambil lokasi di Pulau Potot di utara sampai Pulau Sensa di Selatan. Berdasarkan hasil pengamatan, ternyata penemuan di lapangan dengan Dishidros dan penamaan menurut gazeter cukup signifikan, sehingga diperlukan langkah bersama dalam pendataan dan pencatatan yang disertai kesepahaman penggunaan namanama pulau menurut gazeter secara nasional.

Contoh penamaan pulau baru, misalnya Pulau Potot yang belum ada nama sebelumnya baik dari Dishidros maupun gazeter. Penamaan ini tentu perlu dikoordinasikan antarinstansi atau antarlembaga sehingga penamaan pulau yang terdapat di Dishidros atau gazeter sama. Untuk itu perlu adanya registrasi nama-nama pulau yang sudah teregistrasi secara kelembagaan sehingga tidak ada tumpang tindih penamaan pulau secara gazeter, Dishidros dan peneliti pada berbagai lembaga yang berkompeten terkait pemetaan wilayah/pulau. Contoh lain pada penyebutan Pulau Mentulat di Kecamatan Lingga Utara ini. Penamaan Pulau Mentulat ini memang mengacu pada nama orang yang pernah tinggal di pulau ini. Hanya saja, penamaan Pulau Mentulat di Kecamatan Lingga Utara belum dimasukkan ke dalam data induk Dishidros dan belum dimasukkan ke dalam gazeter nasional.

Penyebutan yang berbeda juga pada penamaan Pulau Sensa yang oleh masyarakat setempat disebut Pulau Sensa, sedangkan pe- namaan menurut Dishidros dan gazeter adalah Pulau Sunsa. Penyebutan Pulau Sensa ini merupakan penyebutan masyarakat setempati terhadap pulau yang mereka kenal. Untuk itu, penamaan gazeter dan Dishidros yang menyebut Pulau Sensa dengan sebutan Pulau Sunsa perlu disesuaikan dengan duduk bersama membahas perbedaan fonologis terhadap penamaan pulau di tiap wilayah yang dinamai masyarakat atau gazeter dan Dishodros. Demikian pula dengan penyebutan pulau lain adalah Pulaubarok. Penyebutan pulau oleh masyarakat setempat adalah Pulaubarok, sedangkan penamaan Dishidros dan gazeter adalah Pulau Barok. Untuk penamaan pulaubarok merupakan sebutan yang diberikan masyarakat terhadap pulau ini, sedangkan Dishidros dan gazeter menyebutnya dengan Pulau Barok. Ini berarti perbedaan Dishidros dan gazeter hanya pada cara mengeja dan penulisan saja, sedangkan berdasarkan penyebutan masyarakat Pulaubarok menyebutnya padu tanpa terpisah secara ortografis.

Perbedaan yang lain adalah dengan penyebutan Pulau Huratik. Penyebutan masyarakat pulau ini adalah Pulau Huratik. Sedangkan menurut penamaan Dishidros dan gazeter adalah Pulau Merati. Penyebutan masyarakat terhadap pulau ini adalah Pulau Huratik tentu memiliki sejarah yang perlu ditelusuri dan acuan penamaan terhadap pulau yang dinamainya. Sedangkan acuan Dishidros dan gazeter menyebut pulau ini adalah Pulau Merati. Perbedaan ini tentu menjadi hal yang perlu dicermati. Penamaan Pulau Huratik perlu dijelaskan lebih lanjut bersamaan dengan penamaan Pulau Merati. Ini menjadi renungan bersama terkait penamaan pulau secara nasional.

Perbedaan penyebutan juga tidak hanya di Kecamatan Senayang, Kecamatan Lingga Utara, dan di Kecamatan Lingga juga terdapat perbedaan yang berhubungan dengan penemuan pulau baru dan perbedaan pengucapan yang masih terlihat adanya hubungan yang 
kasat mata. Berdasarkan data hasil pengamatan di Kecamatan Senayang terdapat 315 pulau dengan rincian 149 pulau teregistrasi dan 166 belum teregistrasi di Dishidros atau gazetir. Pulau yang terdapat di pulau dan Kecamatan Kecamatan Lingga Utara adalah 12 yang teregistrasi 8 pulau dan yang belum teregistrasi 4 pulau, Kecamatan Lingga 53 pulau dengan rincian 37 pulau yang teregistrasi dan 16 pulau yang belum teregistrasi, Kecamatan Singkep barat terdapat 52 pulau pembagian 44 pulau yang sudah teregistrasi dan 8 pulau yang belum teregistrasi, serta Kecamatan Singkep terdapat 23 pulau yang dapat dirincikan 9 pulau sudah teregistrasi dan 14 pulau belum teregistrasi Dishidros dan gazeter nasional.

Perbedaan penamaan pulau baru misalnya Pulau Burung yang belum ada nama sebelumnya baik di Dishidros maupun gazeter. Dalam kasus ini, Dishidros telah mensurvei pulau tersebut tetapi belum diberikan nama, sedangkan gazeter pulau tersebut belum ada. Selain itu penyebutan Pulau Kojong belum ada. Perbedaan penamaan yang masih terlihat pada penyebutan Pulau Cening. Masyarakat setempat menyebutnya dengan Pulau Ceneng, dan menurut gazetir dengan penyebutan Pulau Ceneng. Pulau lain contohnya adalah Pulau Baturesoh, penemuan di lapangan dengan penyebutan Baturesoh, sedangkan penamaan Dishidros adalah Batumaresoh, sedangkan menurut gazeter adalah Batumerasoh.

Perbedaan terjadi pada penemuan pulau baru dan perbedaan penyebutan. Baik yang masih terlihat hubungan maupun tidak berhubungan. Penamaan Pulau Ibul misalnya, yang sebelumnya belum ada nama baik di Peta Laut maupun gazeter. Perbedaan penamaan yang masih terlihat adalah penamaan pulau Bendahara. Penemuan masyarakat sekitar menyebutnya Pulau Bendahara, Dishidros dan gazeter menyebutnya Pulau Bandahara. Contoh lain adalah penyebutan Pulau Pelang. Masyarakat setempat dengan menyebut Pulau
Pelang, sedangkan Dishidros dan gazeter menyebutnya Pulau Pilang.

Perbedaan penamaan yang tidak terlihat adalah dengan penyebutan Pulau Bintun. Menurut temuan di lapangan disebut Pulau Bintun, sedangkan menurut Dishidros adalah Pulau Penganaknoja, dan belum ada menurut gazeter. Pulau lain yang dapat menjadi contoh adalah sebutan Pulau Selambang. Sebutan di lapangan juga dengan Pulau Selambang. Namun penyebutan menurut Dishidros adalah Pulau Bunta dan menurut gazeter adalah dengan sebutan Pulau Buntal.

Perbedaan pengucapan juga terdapat di Kecamatan Singkep. Penyebutan ini masih terlihat adanya hubungan untuk semua pulau yang berbeda. Perbedaan penamaan pulau baru,misalnya Pulau Layak dan Pulau Telur yang belum ada nama sebelumnya pada Dishidros dan penyebutan pada gazeter. Perbedaan yang lain pada penyebutan Pulau Sayak. Masyarakat setempat menyebutnya Pulau Sayak, sedangkan menurut Dishidros dan gazeter menyebutnya dengan Pulau Saya.

\section{PENUTUP}

\section{Simpulan}

Berdasarkan hasil kajian yang telah dilaksanakan didapat bahwa di Kabupaten Lingga terdapat 455 pulau dengan 223 pulau tidak terdaftar namanya dalam dalam daftar pulau Depdagri (Departemen Dalam Negeri) dan 232 pulau yang mempunyai nama. Dari 244 nama pulau bernama dari Peta Laut Dishidros TNI AL dapat diperbaharui dan disurvei. Pulaupulau yang tidak memiliki nama pada peta tersebut berhasil diberi nama sebanyak 211 buah nama pulau. Keragaman bahasa dapat memperkaya nama-nama pulau. Tidak sedikit satu pulau memiliki nama lebih dari satu. Survei ini merupakan langkah konfirmasi dan teknik memperoleh informasi berkaitan nama pulau di suatu wilayah. Penamaan pulau pada dasarnya merujuk pada hal-hal berikut: 1) 
karakter dan potensi pulau, 2) dimensi pulau, bentuk pulau, dan posisi relatif pulau, 3) jabatan dan nama orang yang pernah bermukim di pulau tersebut, 4) legenda atas pulau bersangkutan, 5) penamaan kumpulan atau jajaran pulau dalam satu nama atas pulau bersangkutan, dan 6) penamaan pulau yang mempunyai maksud untuk memperingatkan agar hati-hati.

\section{Daftar Pustaka}

(DEPDAGRI). 2002. Daftar Pulau-Pulau Bernama dan Tidak Bernama Di Indonesia. Jakarta. Dinas Hidro Oseanografi TNI AL.1982.Daftar Pulau-Pulau di Indonesia. Jakarta.

Anonim. 2007. Undang-Undang Republik Indonesia Nomor 27 Tahun 2007 Tentang Pengelolaan Wilayah Pesisir Dan Pulau-Pulau Kecil.

Badan Riset Kelautan dan Perikanan (BRKP). 2003. Buku Panduan Survei Toponimi Pulau-Pulau di Indonesia. Jakarta.

Badan Riset Kelautan dan Perikanan (BRKP), 2003, Buku Panduan Survei Toponimi PulauPulau di Indonesia, Jakarta.

Dahuri, R. 2000. Kebijakan dan Program Nasional Mengembangkan Potensi PulauPulau Kecil Sebagai Pusat

Dahuri,R. 2000. Kebijakan dan Program Nasional Mengembangkan Potensi Pulaupulau Kecil sebagai Pusat Riset dan Industri yang berkelanjutan dengan Berbabis Masyarakat. Jakarta: Makalah Lokakarya Pendekatan Penataan Ruang dalam menunjang Pengembangan Wilayah Pesisir, Pantai, dan Pulau-pulau Kecil.

Dahuri,R., J. Rais, dan Ginting. 2004. Pengelolaan Sumberdaya Wilayah Pesisir dan Lautan secara terpadu. Jakarta: PT.Pradnya Paramitha.

Departemen Dalam Negeri (DEPDAGRI), 2004, Daftar Pulau-Pulau Bernama dan Tidak Bernama di Indonesia, Jakarta.
Dinas Hidro Oseanografi TNI - AL 1982 Daftar Pulau-pulau di Indonesia.Jakarta.

Duranti, Alessandro. 1997. Linguistic Anthropology. Cambridge: Cambridge University Press

Julius. 2009. Identifikasi Pulau-Pulau di Kabupaten Lingga Provinsi Kepulauan Riau Berdasarkan Kaidah Toponimi. Pusat Riset Wilayah Laut dan Sumberdaya Nonhayati-BRKP-DKP. E-Jurnal Ilmu dan Teknologi Kelautan Tropis, Vol. 1., No. 2. Desember 2009.

Kusumah G., dan E.Widjarnako.2007. Identifikasi Teluk dan Tanjung di Teluk Bungus Berdasarkan Kaidah Toponimi Maritim. Jurnal Segara, 3 (2):105-111).

Moleong, Lexy J. (2007) Metodologi Penelitian Kualitatif. Penerbit PT Remaja Rosdakarya Offset: Bandung.

Rais, J. 2003"Arti Penting Toponimi Pulau", Makalah Simposium Kadaster Laut. Jakarta. 14 Desember 2003.

Rais,J. 2003. Arti Penting Toponimi Pulau"Makalah Simposium Kadaster, Jakarta: 14 Desember 2003.

Rais,J.1992.Country Report-Indonesia, 6th Meeting of The UNGEGN for Asia SouthEast and Pacific South-West Division, Wellington.

Saville-Troike, M.(2003).The ethnography of communication: An introduction (3rd) Oxford: Blackwell Publishing.

Sea 1982. UN Publication No. E.83.V.5. New York, N

Spradley James. P. 1980. The Ethnographic Interview. New York: Random House.

Sudaryanto. (1993). Metode dan Teknik Analisis Bahasa. Yogyakarta: Duta wacana University Press.

United Nations. 1983. The Law of the Sea-UN Convention on the Law of the

Willam, J. Samarin. 1988. Ilmu Bahasa Lapangan (diterjemahkan oleh J.S. Badudu). Yogyakarta: Kanisius. 